\title{
Analysis of aerosol absorption properties and transport over North Africa and the Middle East using AERONET data
}

\author{
Ashraf Farahat $^{1,2}$, Hesham El-Askary ${ }^{3,4,5}$, Peter Adetokunbo ${ }^{6}$, and Abu-Tharr Fuad ${ }^{7}$ \\ ${ }^{1}$ Department of Prep Year Physics, College of Applied and Supporting Studies, King Fahd University of Petroleum \& \\ Minerals, Dhahran 31261, Saudi Arabia \\ ${ }^{2}$ Department of Physics, Faculty of Science, Moharam Beek, Alexandria University, Alexandria, 21522, Egypt \\ ${ }^{3}$ Center of Excellence in Earth Systems Modeling and Observations, Chapman University, Orange, CA 92866, USA \\ ${ }^{4}$ Schmid College of Science and Technology, Chapman University, CA 92866, USA \\ ${ }^{5}$ Department of Environmental Sciences, Faculty of Science, Moharam Beek, \\ Alexandria University, Alexandria, 21522, Egypt \\ ${ }^{6}$ Department of Geology, State University of New York at Buffalo, Buffalo, NY 14260, USA \\ ${ }^{7}$ Department of Chemistry and Earth Science, College of Arts \& Science, Qatar University, Doha, Qatar \\ Correspondence to: Hesham El-Askary (elaskary@ chapman.edu)
}

Received: 22 July 2016 - Revised: 4 October 2016 - Accepted: 11 October 2016 - Published: 17 November 2016

\begin{abstract}
In this paper particle categorization and absorption properties were discussed to understand transport mechanisms at different geographic locations and possible radiative impacts on climate. The long-term Aerosol Robotic Network (AERONET) data set (1999-2015) is used to estimate aerosol optical depth (AOD), single scattering albedo (SSA), and the absorption Angström exponent $\left(\alpha_{\mathrm{abs}}\right)$ at eight locations in North Africa and the Middle East. Average variation in SSA is calculated at four wavelengths $(440,675,870$, and $1020 \mathrm{~nm}$ ), and the relationship between aerosol absorption and physical properties is used to infer dominant aerosol types at different locations. It was found that seasonality and geographic location play a major role in identifying dominant aerosol types at each location. Analyzing aerosol characteristics among different sites using AERONET Version 2, Level 2.0 data retrievals and the Hybrid Single Particle Lagrangian Integrated Trajectory model (HYSPLIT) backward trajectories shows possible aerosol particle transport among different locations indicating the importance of understanding transport mechanisms in identifying aerosol sources.
\end{abstract}

Keywords. Atmospheric composition and structure (aerosols and particles; pollution - urban and regional)

\section{Introduction}

Natural and anthropogenic aerosols suspended in the atmosphere are characterized by their diverse sources, varying particle dynamics, lifetimes, interactive mechanisms, and surface and column distributions. Identifying mixtures containing multiple aerosol types like dust, carbon, sea salt, sulfate, or nitrogen is challenging for spaceborne and in situ observations (Chin et al., 2002; Farahat, 2016). Optical techniques are used to estimate particle sizes; however, determining particle types requires more information regarding aerosol sources, trajectories, regional topography, and atmospheric conditions. As for radiative impacts, aerosol characterization and types are major input parameters for obtaining precise climate predictions (Ramanathan et al., 1989; Satheesh and Moorthy, 2005; Farahat et al., 2015). For instance, particle absorption characteristics are used in assessing aerosol emission sources, types, and interaction phases (El-Askary et al., 2015). Aerosol categorization also helps identify dominant aerosol types over a certain geographic location, while climatology effects due to aerosols' spatial and temporal distribution is carried out by examining aerosol sizes along with their absorption characteristics using modeling, satellites, and ground-based measurements (El-Askary, 2006; Kaskaoutis et al., 2012; Aboel Fetouh et al., 2013; Vukovic et al., 2014; Sprigg et al., 2014). It is noteworthy that 


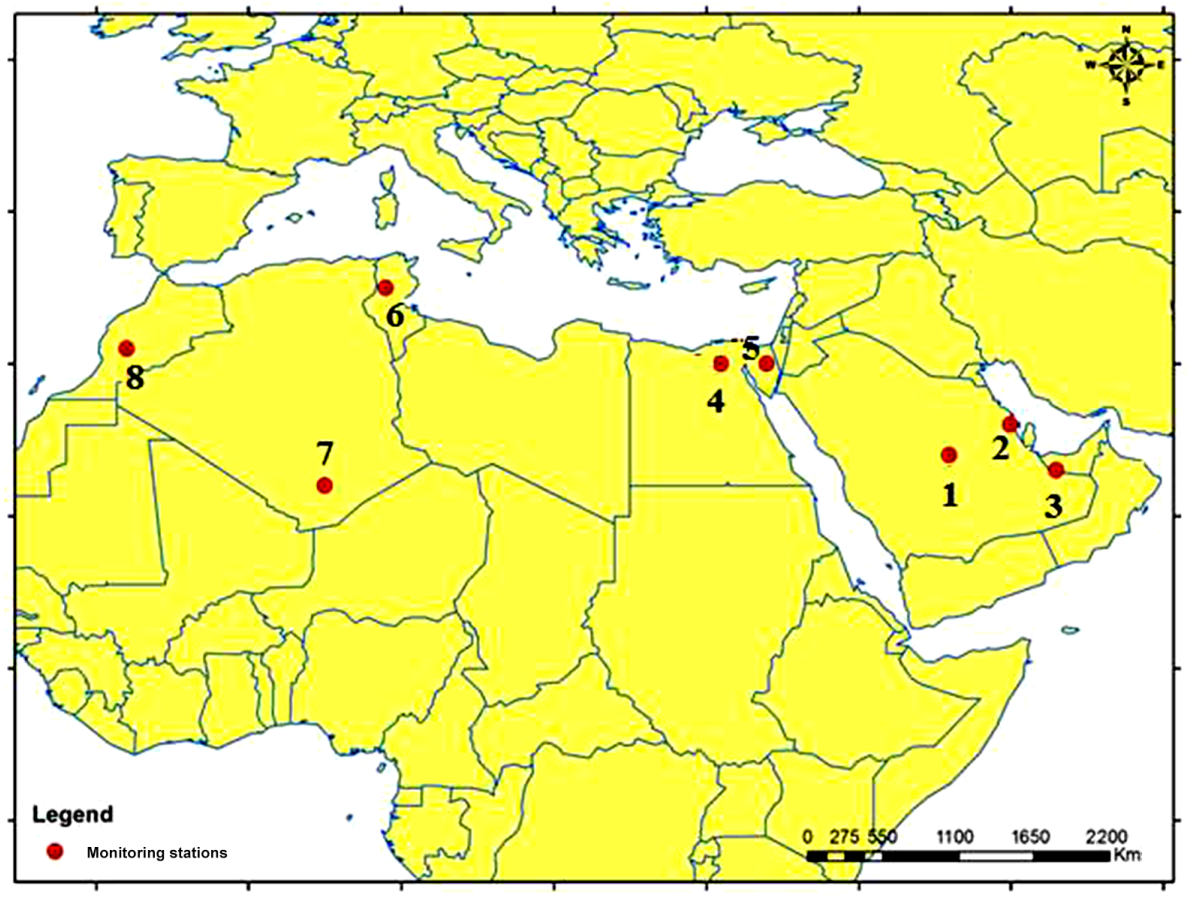

Figure 1. Location map of the AERONET stations used in this study with numbers on the map representing stations' locations: 1 - Solar Village; 2 - Bahrain; 3 - Mezaira; 4 - Cairo; 5 - Sedé Boqer; 6 - Ben Salem, 7 - Tamanrasset; and 8 - Saada.

aerosol optical and microphysical properties can provide significant information to categorize aerosol types. For example, parameters like aerosol optical depth (AOD), the Ångström exponent (AE), aerosol loading, and particle effective radius and different viewing angles are used to depict information regarding aerosol dominant types, emission sources, dust layers, and trajectories (Reid et al., 1999; Kaskaoutis and Kambezidis, 2006; Agarwal et al., 2007; Gobbi et al., 2007; Kalapureddy and Devara, 2008; Russell et al., 2010). Analyzing the derivatives of the AE and particle effective radius is also used to attain information regarding aerosol sizes and types since the particle types are directly correlated with sizes and optical properties (Gerasopoulos et al., 2003, 2011; Alados-Arboledas et al., 2003). The Aerosol Robotic Network (AERONET) data retrievals have been used widely to determine dominant aerosol types and categorization within mixing scenarios through investigating particle size distribution and optical and microphysical properties (Kaufman et al., 1994; Holben et al., 1998; Omar et al., 2005; Qin and Mitchell, 2009; Russell et al., 2010). These studies helped partition major aerosol types including dust, anthropogenic industrial pollution, and mixed and biomass burning aerosols. The absorption Ångström exponent (AAE), defined as the dependence of aerosol optical depth on wavelength as well as single scattering albedo (SSA), defined, as the ratio of scattering to extinction efficiency of aerosol particles, is used to categorize aerosol types. For instance, SSA for dust particles containing hematite and clay results in small absorption over the visible to near-infrared band and strong absorption around $440 \mathrm{~nm}$ (Sokolik and Toon, 1999). On the other hand, for organic carbon (OC), the SSA increases with increasing wavelength where the OC exhibits strong absorption in the visible and ultraviolet range, while for aerosols composed of black carbon (BC) particles, the SSA is inversely proportional to the wavelength. Sulfate and other hygroscopic aerosols do not show significant SSA spectral dependence (Dubovik et al., 2002). Therefore, mixed aerosol containing sulfates, BC, and OC could produce an indistinct SSAwavelength dependence due to the varying spectral effects of aerosol mixtures in the atmosphere (Dubovik et al., 2002).

In this study we investigate aerosol characteristics over North Africa and the Middle East using eight AERONET sites in the region, namely, Solar Village $\left(24^{\circ} \mathrm{N}, 46^{\circ} \mathrm{E}\right)$, Bahrain $\left(26^{\circ} \mathrm{N}, 50^{\circ} \mathrm{E}\right)$, Mezaira $\left(23^{\circ} \mathrm{N}, 53^{\circ} \mathrm{E}\right)$, Cairo $\left(30^{\circ} \mathrm{N}, 31^{\circ} \mathrm{E}\right)$, Sedé Boqer $\left(30^{\circ} \mathrm{N}, 34^{\circ} \mathrm{E}\right)$, Tamanrasset $\left(22^{\circ} \mathrm{N}, 5^{\circ} \mathrm{E}\right)$, Saada $\left(31^{\circ} \mathrm{N}, 8^{\circ} \mathrm{W}\right)$, and Ben Salem $\left(35^{\circ} \mathrm{N}\right.$, $9^{\circ} \mathrm{E}$ ) (Fig. 1). The analysis was based on data availability (at least 4 years of successive data measurements from 1999 to 2015) except for the Ben Salem site where the analysis was based on 2013-2015 data only. Previous studies (Table 1) classified dominant aerosol types at some of these sites based on their geographic locations into clear, dust, pollution, and mixed; however, the effect of seasonality and aerosol transport was not fully investigated for those sites. Dust and biomass particles could be dominating over some sites; however, other aerosol types could also exist over the 
Table 1. Previous studies categorizing aerosol types over some of the AERONET sites presented in this work.

\begin{tabular}{|c|c|c|}
\hline Aerosol type - region(s) & AERONET sites & References \\
\hline Biomass - North Africa & Cairo & $\begin{array}{l}\text { El-Askary and Kafatos (2008); } \\
\text { Marey et al. (2010, 2011); } \\
\text { El-Metwally et al. (2008) }\end{array}$ \\
\hline Mixed - Middle East & Sedé Boqer & $\begin{array}{l}\text { Derimian et al. (2006); } \\
\text { Eck el. (2010) }\end{array}$ \\
\hline Dust - Middle East & $\begin{array}{l}\text { Solar Village, Bahrain, } \\
\text { Mezaira }\end{array}$ & $\begin{array}{l}\text { Dubovik and King (2000); } \\
\text { Dubovik et al. (2002) }\end{array}$ \\
\hline Different aerosol types & All Sites & Holben et al. (2001) \\
\hline Mixed - North Africa & $\begin{array}{l}\text { Saada, Tamanrasset, } \\
\text { Ben Salem }\end{array}$ & $\begin{array}{l}\text { Basart et al. (2009); } \\
\text { Abdi Vishkaee et al. (2012) }\end{array}$ \\
\hline
\end{tabular}

site during the analysis period (Takemura et al., 2000; ElAskary and Kafatos, 2008). Although previous studies categorized sites based on their most dominant aerosol particles, they did not explicitly explore the variability in aerosol types over each site. As seasonal changes, major dust events, and human activities could largely affect dominant aerosol types (El-Metwally et al., 2008). Each location could have more than one dominating particle category during the year. In this work, we analyze aerosol volume size parameters and compare them with single scattering albedo at each site. The absorption parameters are calculated at various wavelengths. Last, aerosol variability and possible transport from one site to another is investigated. This study highlights this variability in aerosol categorization over each site based on these factors. It also shows possible aerosol transport between sites. The following criteria are used to categorize aerosol particles based on AOD ( $\tau$ a 675$)$ and the Ångström exponent ( $\alpha 675 / 440$ ) (El-Askary et al., 2009). Cases with $\tau$ a675 $\geq 0.3$ and $\alpha 675 / 440 \leq 0.4$ are classified as dust; $\tau \mathrm{a} 675<0.3$ and $\alpha 675 / 440>0.8$ are classified as pollution; $\tau \mathrm{a} 675 \geq 0.3$ and $\alpha 675 / 440>0.4$ are classified as mixed; $\tau$ a $675<0.3$ are classified as clean.

\section{Instrumentation, data, and methodology}

AERONET is an array of sun photometers globally distributed to measure columnar spectral AOD and water vapor in a wavelength range of 340 to $1640 \mathrm{~nm}$ and temporal resolution of 600 to $900 \mathrm{~s}$. The network also retrieves columnar optical aerosol properties (e.g., aerosol size distribution, volume mean radius, volume concentration, and multi wavelength single scattering albedo at 440, 675, 870, and $1020 \mathrm{~nm}$ (Holben et al., 1998)). This takes place by fitting measurements of the spectral AOD and sky radiances to radiative transfer calculations (Dubovik and King, 2000). AERONET data retrievals comprise 1-2\% estimated uncertainty (Eck et al., 1999) with the highest uncertainty near UV wavelengths
(Holben et at., 1998). We used the AERONET Version 2, Level 2.0 products that contain retrievals for 116 different aerosol parameters including, aerosol volume size distribution (AVSD; $\mathrm{d} V(r) / \mathrm{d} \ln r\left(\mu \mathrm{m}^{3} / \mu \mathrm{m}^{2}\right)$ ) retrieved in 22 logarithmically equidistant radial bins spanning the range of particle radii $0.05 \mu \mathrm{m} \leq r \leq 15 \mu \mathrm{m}$, the real and imaginary parts of the refractive index $(\mathrm{CRI}-\mathrm{R}(\lambda), \mathrm{CRI}-\mathrm{I}(\lambda))$, and the optical parameters (AOD $(\lambda)$ and SSA) centered at four wavelengths (440, 675, 870, and $1020 \mathrm{~nm}$; Taylor et al., 2014). Version 2 inversion products also provide the mean geometric radii of the fine and coarse modes, their standard deviation, and their volume concentrations. This is of particular importance for our analysis owing to the mixing scenarios observed over North Africa and the Gulf region.

The AERONET inversion code provides aerosol optical properties by measuring spectral direct beam and diffuse solar radiation. Water vapor and columnar spectral AOD characteristics can be retrieved from the AERONET direct-sun measurements with a temporal resolution of $\sim 600-900 \mathrm{~s}$ and 1-2\% typical AOD uncertainty (Holben et al., 1998; Eck et al., 1999). Depending on the site, the data are typically provided at a wavelength range of 340 to $1640 \mathrm{~nm}$, together with Ångström exponent $\alpha$ over certain wavelength ranges. AERONET pre-version 1 (pre-release of Version 1, 2003) data have been applied to categorize aerosols based on their optical characteristics (Dubovic et al., 2002, and Russell et al., 2010). The AERONET Version 2 data, 2006, provided more precise calculations of reflectance over bright surfaces compared to Version 1. For example, in Saudi Arabia, Bahrain, and the United Arab Emirates, Version 2 provided more consistent SSA over small islands vs. vast bright desert, with an SSA difference of less than 0.01 compared to 0.03 for Version 1.

AERONET data retrievals Version 2, Level 2.0 (Smirnov et al., 2000, 2002) are used to derive the extinction Ångström exponent $\left(\alpha_{\text {ext }}\right)$ using the measured aerosol optical properties and AOD spectral dependence $\left(\tau_{\text {ext }}\right)$ with wavelength $(\lambda)$ 

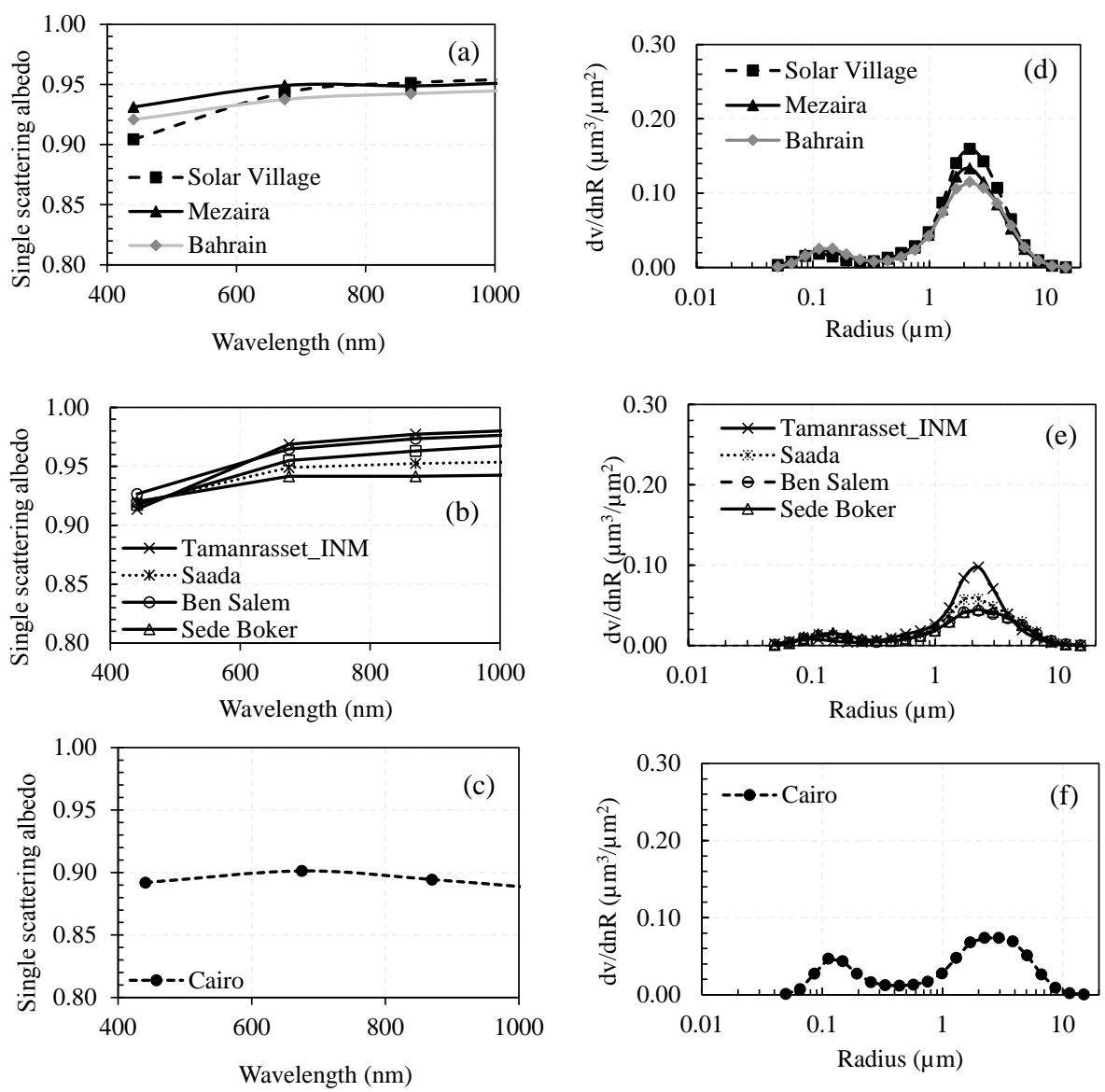

Figure 2. Characteristics of the single scattering albedo (SSA) at (a) Solar Village, Bahrain, and Mezaira; (b) Tamanrasset, Saada, Ben Salem, and Sedé Boqer; (c) Cairo. Volume size distribution at the eight sites: (d) Solar Village, Bahrain, and Mezaira; (e) Tamanrasset, Saada, Ben Salem, and Sedé Boqer; (f) Cairo.

(Ångström, 1964):

$\alpha_{\text {ext }}=-\mathrm{d} \ln \left[\tau_{\mathrm{ext}}(\lambda)\right] / \mathrm{d} \ln (\lambda)$.

Fine- and coarse-mode particles can be identified by calculating the linear regression of $\ln \left(\tau_{\text {ext }}\right)$ vs. $\ln (\lambda)$, where values close to 2 indicate fine mode and 0 represents coarse mode (Nakajima et al., 1989). The absorption Ångström exponent $\left(\alpha_{\text {abs }}\right)$ can also be calculated using

$\alpha_{\mathrm{abs}}=-\mathrm{d} \ln \left[\tau_{\mathrm{abs}}(\lambda)\right] / \mathrm{d} \ln (\lambda)$.

Aerosol particle physical characteristics affect $\alpha_{\mathrm{abs}}$, for example $\alpha_{\text {abs }}$ varies from less than 1.0 and up to 1.6 for large black carbon particles $(r>0.1 \mu \mathrm{m})$ based on their core size and coating structure (Kondo et al., 2009). Black carbon particles are characterized by their small radius and spherical shapes, which results in $\alpha_{\text {abs }}$ values of $\sim 1.0$ (Petzold et al., 1997). Dubovik et al. (2002) also showed that $\alpha_{\text {abs }}$ varies between 1.2 and 3.0 for dust, 1.2 and 2.0 for pollution (biomass only), and 0.75 and 1.3 for mixed aerosols.

\section{Results}

\subsection{Aerosol categorization using SSA}

Aerosol absorption properties over the eight locations under investigation are represented in Fig. 2 and Table 2. The SSA spectral behavior agrees with Giles et al. (2012) and Dubovik et al. (2002) but with an average decrease of 0.02 at the Solar Village and Bahrain sites. The averaged optical properties, with aerosol data listed and volume size distribution at each site (Table 2), shows there is a lower SSA variability at Solar Village, Mezaira, and Bahrain compared to the other sites. The small SSA variability at those three sites is attributed to physical (size and shape) similarities between particle grains produced by the vast sand area surrounding the sites. The SSA standard deviations calculated for this study are 0.004 lower and 0.008 greater than Dubovik et al. (2002) for the Solar Village and Bahrain sites, respectively. The difference between Table 2 and Dubovik et al. (2002) for these two sites is due to applying improved Level 2.0 AERONET data retrievals and utilizing a larger data set. Pure dust could be dis- 
Table 2. Aerosols absorption and physical properties categorized by aerosol types, for sample stations, using AERONET Version 2, Level 2.0 data retrievals. Some locations may experience other aerosol types during different seasons (Cairo, for instance). The spectral single scattering albedo (SSA) is listed first followed by the standard deviations based on monthly values. EMA: Egyptian Meteorology Authority.

\begin{tabular}{|c|c|c|c|c|c|}
\hline Site & Data range & SSA 440/675/870/1020 & $\alpha_{\mathrm{abs}}$ & $\alpha_{\text {ext }}$ & $\mathrm{N}$ \\
\hline \multicolumn{6}{|c|}{ Dust } \\
\hline Solar Village & 1999-2015 & $\begin{array}{l}0.9 / 0.94 / 0.95 / 0.95 \\
0.0225 / 0.0261 / 0.0269 / 0.0276\end{array}$ & $1.5 \pm 0.54$ & $0.35 \pm 0.13$ & 4080 \\
\hline Bahrain & 1996-2006 & $\begin{array}{l}0.92 / 0.94 / 0.94 / 0.94 \\
0.0296 / 0.0265 / 0.0280 / 0.0297\end{array}$ & $1.3 \pm 0.47$ & $0.58 \pm 0.22$ & 1320 \\
\hline Mezaira & 2004-2015 & $\begin{array}{l}0.93 / 0.95 / 0.95 / 0.95 \\
0.0178 / 0.0181 / 0.0223 / 0.0243\end{array}$ & $1.2 \pm 0.18$ & $0.49 \pm 0.44$ & 1500 \\
\hline \multicolumn{6}{|c|}{ Biomass } \\
\hline Cairo EMA & 2005-2007 & $\begin{array}{l}0.89 / 0.90 / 0.90 / 0.90 \\
0.0203 / 0.0234 / 0.0275 / 0.0306\end{array}$ & $1.2 \pm 0.32$ & $0.88 \pm 0.44$ & 360 \\
\hline Cairo Univ. & 2004-2005 & $\begin{array}{l}0.89 / 0.90 / 0.88 / 0.87 \\
0.0140 / 0.0268 / 0.0357 / 0.0435\end{array}$ & $0.94 \pm 0.31$ & $0.83 \pm 0.35$ & 210 \\
\hline \multicolumn{6}{|c|}{ Mixed } \\
\hline Sedé Boqer & 2010-2015 & $\begin{array}{l}0.92 / 0.94 / 0.94 / 0.94 \\
0.0240 / 0.0273 / 0.0345 / 0.0373\end{array}$ & $1.2 \pm 0.27$ & $0.72 \pm 0.45$ & 3180 \\
\hline Saada & 2003-2015 & $\begin{array}{l}0.92 / 0.95 / 0.95 / 0.95 \\
0.0226 / 0.0206 / 0.0249 / 0.0279\end{array}$ & $1.3 \pm 0.21$ & $0.57 \pm 0.48$ & 1560 \\
\hline Ben Salem & 2013-2015 & $\begin{array}{l}0.93 / 0.96 / 0.97 / 0.98 \\
0.0211 / 0.0129 / 0.0126 / 0.0129\end{array}$ & $1.9 \pm 0.23$ & $0.62 \pm 0.71$ & 420 \\
\hline Tamanrasset & 2000-2015 & $\begin{array}{l}0.91 / 0.97 / 0.98 / 0.98 \\
0.0139 / 0.0072 / 0.0054 / 0.0049\end{array}$ & $2.1 \pm 0.09$ & $0.25 \pm 0.76$ & 540 \\
\hline
\end{tabular}

tinguished for values of $\alpha_{\text {ext }}$ less than 0.2 (Kim et al., 2011). Solar Village, Bahrain, and Mezaira have $\alpha_{\mathrm{ext}} \geq 0.3$, indicating a possible incursion by other aerosols. This is more recognized at the Bahrain site due to the presence of fine particles produced from industrial activities similar to other locations (Gathman, 1983; Gras, 1995; Kalapureddy and Devara, 2008; Park et al., 2015).

Cairo is known for its widespread biomass burning activities observed during fall when episodes of ash burning from agriculture waste take place (El-Askary and Kafatos, 2008; Marey et al., 2010, 2011); however, other factors could also contribute to pollution, such as traffic and industry. Compared to other particle types, the biomass particles are known to have the largest SSA variability due to various combustion phases and fuel types (Eck et al., 2003); however, only a small SSA difference $(\sim 0.013)$ is observed between Cairo and the Solar Village, Bahrain, and Mezaira site. This is an indication of a possible mixing pattern between biomass and dust over Cairo (El-Askary and Kafatos, 2008; El-Metwally et al., 2008).

The similarity in the SSA characteristics between the Saada, Tamanrasset, and Ben Salem sites, on the one hand, and Solar Village, Bahrain, and Mezaira (Fig. 2) with a strong absorption at $440 \mathrm{~nm}$, on the other hand, is an indication of the dust dominance contribution to the Saada, Taman- rasset, and Ben Salem sites. The increased absorption at these three sites could also be due to increased hematite percentage in the dust that could lead to an increased absorption in the blue to near-infrared wavelength band (Sokolik and Toon. 1999). The average SSA values for all locations are $\sim 0.91$ $(440 \mathrm{~nm}), 0.94(675 \mathrm{~nm}), 0.95(870 \mathrm{~nm})$, and $0.95(1020 \mathrm{~nm})$ and reveal insignificant changes with respect to the SSA for all sites (Fig. 2, and Table 2). This is a sign of possible mixing scenarios through transporting aerosols between different sites.

Figure $2 \mathrm{~d}-\mathrm{f}$ show that both small and large particles exist with large particles dominating, as is shown by the two peaks at $\sim 0.1$ and $\sim 4 \mu \mathrm{m}$ with high dust domination over the Solar Village, Bahrain, and Mezaira locations. The high concentration of small size particles with $\sim 0.1 \mu \mathrm{m}$ over Cairo is an indication of high pollution over this location.

\subsection{Aerosol (pollution/dust) discrimination using Ångström exponent}

The AERONET Lev 2, Ver 2.0 data retrievals are used along with Eq. 2 to calculate average absorption aerosol optical $\operatorname{depth}\left(\tau_{\mathrm{abs}}\right)$ and the absorption Ångström exponent $\left(\alpha_{\mathrm{abs}}\right)$ for aerosol particles at the Solar Village, Bahrain, and Mezaira (Fig. 3, Table 2). A comparison with Giles et al. (2012) shows a large difference in $\alpha_{\mathrm{abs}}(+0.47)$, and with Dubovik 

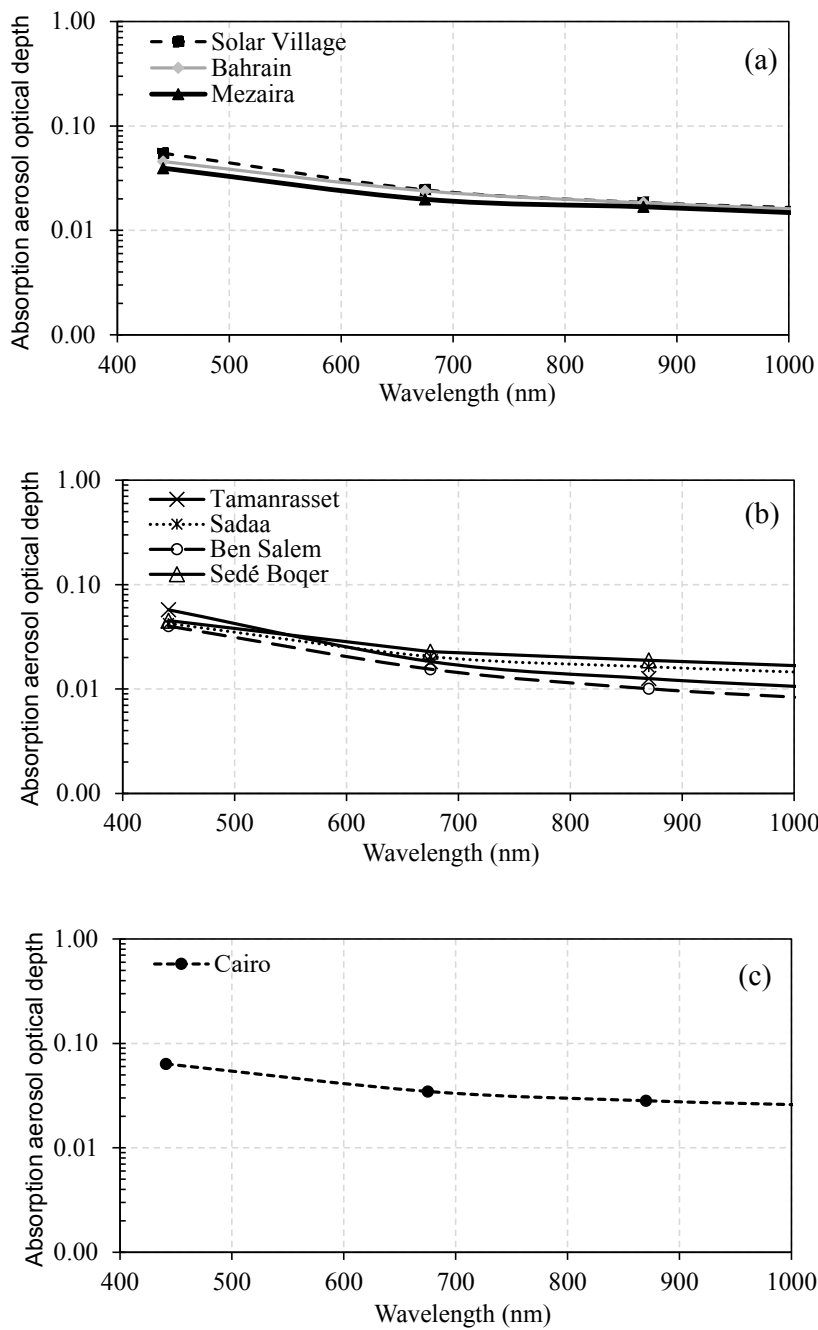

Figure 3. Absorption aerosol optical depth $\left(\tau_{\mathrm{abs}}\right)$ average grouped by the dominant aerosol type at the eight sites using AERONET Version 2, Level 2.0 data retrievals: (a) Solar Village, Bahrain, and Mezaira; (b) Tamanrasset, Saada, Ben Salem, and Sedé Boqer; (c) Cairo.

et al. (2002), Giles et al. (2012), and Russell et al. (2010), the difference in $\alpha_{\text {abs }}$ over Solar Village is $(+0.3)$. For the Tamanrasset, Saada, Ben Salem, Sedé Boqer, and Cairo sites, the average $\alpha_{\mathrm{abs}}$ is comparable to Russell et al. (2010) and Giles et al. (2012).

The above results can give a general indication regarding aerosol categorizations at different locations and possible particle transport mechanism; however, they do not show the seasonality effect on particle dominance over a certain location. Long-range frequency of occurrence of clean, mixed, dust, and pollution aerosol categories along with their AOD and Ångström exponent measurements over the Solar Village, Bahrain, Mezaira, Sedé Boqer, Cairo, Saada, Tamanrasset, and Ben Salem stations can provide detailed information of the aerosol categorization and transport patterns
Table 3. Seasonal dust domination over study locations. EMA: Egyptian Meteorology Authority.

\begin{tabular}{|c|c|c|c|}
\hline & & Dust & \\
\hline & Date & $\tau \mathrm{a} 675$ & $\alpha 675 / 440$ \\
\hline \multirow[t]{18}{*}{ Solar Village } & Jun 2000 & 0.334636 & 0.123701 \\
\hline & Jul 2000 & 0.554335 & 0.209781 \\
\hline & May 2003 & 0.647241 & 0.089842 \\
\hline & Jun 2003 & 0.427258 & 0.259769 \\
\hline & May 2004 & 0.478263 & 0.135207 \\
\hline & May 2006 & 0.675854 & 0.136249 \\
\hline & Apr 2007 & 0.565676 & 0.216993 \\
\hline & May 2007 & 0.525404 & 0.229953 \\
\hline & Jun 2007 & 0.512271 & 0.222469 \\
\hline & May 2008 & 0.603597 & 0.219008 \\
\hline & Jun 2008 & 0.581412 & 0.136546 \\
\hline & Apr 2009 & 0.525053 & 0.160235 \\
\hline & May 2009 & 0.683702 & 0.154192 \\
\hline & Jun 2009 & 0.841581 & 0.180778 \\
\hline & Mar 2010 & 0.427101 & 0.230243 \\
\hline & May 2011 & 0.635264 & 0.156087 \\
\hline & May 2012 & 0.580928 & 0.220351 \\
\hline & Jun 2012 & 0.549905 & 0.34144 \\
\hline Bahrain & May 2006 & 0.451065 & 0.300185 \\
\hline \multirow[t]{3}{*}{ Mezaira } & May 2010 & 0.40083 & 0.363177 \\
\hline & Jun 2010 & 0.487617 & 0.372444 \\
\hline & Mar 2012 & 0.591211 & 0.306378 \\
\hline Cairo EMA & Apr 2005 & 0.440351 & 0.609703 \\
\hline \multirow[t]{3}{*}{ Saada } & Jul 2007 & 0.421629 & 0.392435 \\
\hline & Jul 2010 & 0.503962 & 0.312905 \\
\hline & Aug 2011 & 0.399346 & 0.387933 \\
\hline
\end{tabular}

among sites. Tables 3-6 and Fig. 4a-c show the effect of seasonality in determining the dominant aerosol particles at each location. Table 3 shows that natural dust particles dominate over the Solar Village, Bahrain, and Mezaira sites during March-June where dust storms events are active during these months. Anthropogenic aerosols dominate over the sites mostly during September-December (Table 4) due to common windstorms (Said and Kadry, 1994) blowing during these months, which help in transporting pollutants and other anthropogenic aerosols. A mixed aerosol pattern is observed all year around over the three sites but mostly during July and August (Table 5), and the air is mostly clean during November and December (Table 6). AOD values and Ångström exponents played a major role in defining the abovementioned four aerosol categories represented in Tables 3-6.

Data showed that high pollution over Cairo during the autumn months (Table 4, Fig. 4e) as a result of yearly events where farmers burn their leftover rice straw, causing severe pollution and 2 to 3 months of potential complications for respiratory and heart disease patients (Marey et al., 2010). It is interesting to observe similar pollution patterns over 
Table 4. Seasonal pollution domination over study locations.

\begin{tabular}{|c|c|c|c|}
\hline & & Pollution & \\
\hline \multirow[t]{12}{*}{ Solar Village } & Sep 1999 & 0.244095 & 0.867438 \\
\hline & Oct 2002 & 0.183753 & 0.926034 \\
\hline & Oct 2004 & 0.167256 & 0.906812 \\
\hline & Nov 2005 & 0.191312 & 0.86848 \\
\hline & Dec 2006 & 0.196497 & 1.019745 \\
\hline & Oct 2007 & 0.175421 & 1.057346 \\
\hline & Nov 2007 & 0.129448 & 0.904911 \\
\hline & Dec 2007 & 0.176361 & 0.899631 \\
\hline & Dec 2009 & 0.172281 & 0.825395 \\
\hline & Dec 2010 & 0.13846 & 1.046825 \\
\hline & Oct 2012 & 0.202834 & 1.166223 \\
\hline & Dec 2012 & 0.217803 & 0.858837 \\
\hline \multirow[t]{11}{*}{ Bahrain } & Oct 2004 & 0.291991 & 1.081508 \\
\hline & Nov 2004 & 0.271147 & 1.07103 \\
\hline & Dec 2004 & 0.181128 & 1.298788 \\
\hline & Jan 2005 & 0.251857 & 0.984849 \\
\hline & Feb 2005 & 0.246111 & 0.881871 \\
\hline & Sep 2005 & 0.255824 & 0.852505 \\
\hline & Oct 2005 & 0.251038 & 1.219987 \\
\hline & Nov 2005 & 0.236496 & 1.125288 \\
\hline & Dec 2005 & 0.214268 & 1.20609 \\
\hline & Jan 2006 & 0.245147 & 1.04383 \\
\hline & Sep 2006 & 0.288577 & 0.890148 \\
\hline \multirow[t]{14}{*}{ Mezaira } & Sep 2007 & 0.254272 & 0.888841 \\
\hline & Oct 2007 & 0.202455 & 1.132523 \\
\hline & Dec 2007 & 0.13286 & 1.12398 \\
\hline & Oct 2008 & 0.238893 & 0.825587 \\
\hline & Nov 2008 & 0.145263 & 1.247883 \\
\hline & Nov 2009 & 0.162022 & 1.004461 \\
\hline & Dec 2009 & 0.168218 & 1.153539 \\
\hline & Jan 2010 & 0.122813 & 1.353932 \\
\hline & Nov 2010 & 0.176654 & 1.398123 \\
\hline & Sep 2011 & 0.294382 & 0.932607 \\
\hline & Oct 2011 & 0.219481 & 0.943015 \\
\hline & Nov 2013 & 0.154019 & 1.215744 \\
\hline & Dec 2013 & 0.119431 & 1.156596 \\
\hline & Jan 2014 & 0.147758 & 1.236338 \\
\hline \multirow[t]{8}{*}{ Sedé Boqer } & Aug 1998 & 0.174121 & 1.288291 \\
\hline & Sep 1998 & 0.166246 & 1.11584 \\
\hline & Jul 1999 & 0.132953 & 1.250256 \\
\hline & Aug 1999 & 0.136223 & 1.21218 \\
\hline & Sep 1999 & 0.147045 & 1.031709 \\
\hline & Aug 2000 & 0.158882 & 1.082329 \\
\hline & Jul 2001 & 0.137293 & 1.095682 \\
\hline & Aug 2001 & 0.177398 & 1.23571 \\
\hline
\end{tabular}

Sedé Boqer (Fig. 4c) during the same time of the year indicating a possible aerosol transport between different sites. Data show that dust particles dominate over Cairo during the spring season with the yearly khamsin sandstorm blowing over the country during this time. These results agree with a high fine-particle concentration found over Cairo (Fig. 2f).
Table 4. Continued.

\begin{tabular}{|c|c|c|c|}
\hline \multirow{2}{*}{ Sedé Boqer } & \multicolumn{3}{|c|}{ Pollution } \\
\hline & Jul 2003 & 0.107682 & 1.340217 \\
\hline & Nov 2003 & 0.128659 & 1.037325 \\
\hline & Jun 2004 & 0.112256 & 1.090375 \\
\hline & Jul 2004 & 0.124242 & 1.091038 \\
\hline & Aug 2004 & 0.107275 & 1.238889 \\
\hline & Sep 2004 & 0.129063 & 1.170213 \\
\hline & Oct 2004 & 0.188042 & 1.002594 \\
\hline & May 2005 & 0.160178 & 1.013421 \\
\hline & Jun 2005 & 0.162945 & 1.061923 \\
\hline & Jul 2005 & 0.117386 & 1.30013 \\
\hline & Aug 2005 & 0.141749 & 1.235765 \\
\hline & Sep 2005 & 0.135074 & 1.098233 \\
\hline & Oct 2005 & 0.130501 & 1.167848 \\
\hline & Nov 2005 & 0.095973 & 1.33766 \\
\hline & Jul 2006 & 0.130309 & 1.324776 \\
\hline & Aug 2006 & 0.137575 & 1.143954 \\
\hline & Sep 2006 & 0.147521 & 1.107143 \\
\hline & Oct 2006 & 0.126813 & 1.211563 \\
\hline & Nov 2006 & 0.091998 & 1.324415 \\
\hline & Jan 2007 & 0.090471 & 1.242201 \\
\hline & Jul 2007 & 0.124851 & 1.234827 \\
\hline & Aug 2007 & 0.124037 & 1.25921 \\
\hline & Dec 2007 & 0.069032 & 1.245291 \\
\hline & Jul 2008 & 0.099229 & 1.211103 \\
\hline & Aug 2008 & 0.177886 & 1.259835 \\
\hline & Oct 2008 & 0.1479 & 1.201744 \\
\hline & Nov 2008 & 0.085567 & 1.351784 \\
\hline & Dec 2008 & 0.069011 & 1.247196 \\
\hline & Jun 2009 & 0.109275 & 1.033012 \\
\hline & Jul 2009 & 0.118304 & 1.176056 \\
\hline & Aug 2009 & 0.113501 & 1.401656 \\
\hline & Sep 2009 & 0.120057 & 1.335245 \\
\hline & Oct 2009 & 0.194083 & 1.044277 \\
\hline & Nov 2009 & 0.094559 & 1.457584 \\
\hline & Dec 2009 & 0.101495 & 1.294266 \\
\hline & Jan 2010 & 0.090991 & 1.131905 \\
\hline & Jul 2010 & 0.17596 & 1.051998 \\
\hline & Aug 2010 & 0.191311 & 1.034425 \\
\hline & Nov 2010 & 0.12169 & 1.095045 \\
\hline & Mar 2011 & 0.118081 & 1.0387 \\
\hline & Jun 2011 & 0.116627 & 1.305029 \\
\hline & Jul 2011 & 0.158914 & 1.298425 \\
\hline & Aug 2011 & 0.121009 & 1.387253 \\
\hline & Sep 2011 & 0.131061 & 1.463028 \\
\hline & Oct 2011 & 0.141843 & 1.098022 \\
\hline & Nov 2011 & 0.096901 & 1.433644 \\
\hline
\end{tabular}

Dust particles dominate over the Saada site (Table 3, Fig. 4f) during July and August, which is not the usual sand storm season (February-April) over Morocco (Goudie and Middleton, 2001). However, this could be attributed to the effect of single dust events sweeping off the coast of Morocco, like the ones on 15 August 2005 and on 7 August 2015. 
Table 4. Continued.

\begin{tabular}{|c|c|c|c|}
\hline & & Pollution & \\
\hline \multirow[t]{15}{*}{ Sedé Boqer } & Jun 2012 & 0.137811 & 1.050994 \\
\hline & Jul 2012 & 0.123867 & 1.300216 \\
\hline & Aug 2012 & 0.104786 & 1.323267 \\
\hline & Sep 2012 & 0.14309 & 1.177 \\
\hline & Oct 2012 & 0.143002 & 1.305639 \\
\hline & Nov 2012 & 0.111837 & 1.22663 \\
\hline & Dec 2012 & 0.075735 & 1.083349 \\
\hline & Jun 2013 & 0.140469 & 1.004892 \\
\hline & Jul 2013 & 0.097441 & 1.305687 \\
\hline & Aug 2013 & 0.094034 & 1.352441 \\
\hline & Jul 2014 & 0.10121 & 1.384998 \\
\hline & Aug 2014 & 0.096176 & 1.409582 \\
\hline & Sep 2014 & 0.122792 & 1.139754 \\
\hline & Oct 2014 & 0.1075 & 1.349438 \\
\hline & Nov 2014 & 0.078158 & 1.212458 \\
\hline \multirow[t]{4}{*}{ Cairo Univ. } & Nov 2004 & 0.214229 & 1.175515 \\
\hline & Dec 2004 & 0.202082 & 1.291856 \\
\hline & Jan 2005 & 0.228575 & 1.118635 \\
\hline & Mar 2005 & 0.219945 & 1.223339 \\
\hline \multirow[t]{8}{*}{ Cairo EMA } & May 2005 & 0.247344 & 1.063784 \\
\hline & Jun 2005 & 0.288959 & 1.109003 \\
\hline & Jul 2005 & 0.255777 & 1.319079 \\
\hline & Aug 2005 & 0.261915 & 1.294556 \\
\hline & Sep 2005 & 0.26998 & 1.118464 \\
\hline & Nov 2005 & 0.234297 & 1.300921 \\
\hline & Dec 2005 & 0.251722 & 1.23849 \\
\hline & Jan 2006 & 0.231234 & 1.349487 \\
\hline Tamanrasset & Jan 2013 & 0.022714 & 1.100667 \\
\hline \multirow[t]{7}{*}{ Saada } & May 2007 & 0.129623 & 1.039977 \\
\hline & Nov 2007 & 0.118411 & 1.024152 \\
\hline & Dec 2007 & 0.072318 & 1.45022 \\
\hline & Jan 2008 & 0.062712 & 1.449272 \\
\hline & May 2008 & 0.132574 & 1.080527 \\
\hline & Dec 2011 & 0.082039 & 1.267306 \\
\hline & Feb 2012 & 0.10336 & 1.119926 \\
\hline \multirow[t]{2}{*}{ Ben Salem } & Aug 2013 & 0.177932 & 1.042051 \\
\hline & Apr 2014 & 0.114515 & 1.000073 \\
\hline
\end{tabular}

Tamanrasset site data indicate that dust dominates (Fig. 4g) during March-April, which falls within the yearly dust storm events over Algeria and in October-November where individual dust events blow through the Sahara. Clear weather conditions are also found all year around. The Ben Salem (Fig. 4h) station does not provide enough data during the study period but most of the data collected point to a mixing aerosol particle pattern during May-July. Time series of the AOD and Ångström exponent show a data gap over the Mezaira, Cairo, Saada, and Ben Salem stations where the sun photometers were not operating for an extended period.
Table 5. Seasonal mixing particle domination over study locations.

\begin{tabular}{|c|c|c|c|}
\hline & & Mixed & \\
\hline \multirow[t]{17}{*}{ Solar Village } & May 1999 & 0.341644 & 0.426579 \\
\hline & Aug 2000 & 0.398135 & 0.634875 \\
\hline & Jul 2003 & 0.317711 & 0.510211 \\
\hline & Aug 2003 & 0.359311 & 0.60482 \\
\hline & Jul 2005 & 0.359354 & 0.441735 \\
\hline & Aug 2005 & 0.303309 & 0.559758 \\
\hline & Jul 2006 & 0.31427 & 0.411585 \\
\hline & Aug 2006 & 0.420226 & 0.519463 \\
\hline & Sep 2007 & 0.304047 & 0.745258 \\
\hline & Aug 2009 & 0.504137 & 0.400734 \\
\hline & Sep 2009 & 0.353579 & 0.482951 \\
\hline & Feb 2011 & 0.390127 & 0.418135 \\
\hline & Jun 2011 & 0.607849 & 0.409912 \\
\hline & Jul 2011 & 0.49618 & 0.573132 \\
\hline & Aug 2011 & 0.37496 & 0.639556 \\
\hline & Jul 2012 & 0.383708 & 0.739601 \\
\hline & Aug 2012 & 0.328888 & 0.81767 \\
\hline \multirow[t]{12}{*}{ Bahrain } & Mar 2005 & 0.309838 & 0.642457 \\
\hline & Apr 2005 & 0.409481 & 0.472898 \\
\hline & May 2005 & 0.510207 & 0.479964 \\
\hline & Jun 2005 & 0.379552 & 0.40134 \\
\hline & Jul 2005 & 0.50564 & 0.543538 \\
\hline & Aug 2005 & 0.396494 & 0.794101 \\
\hline & Feb 2006 & 0.316549 & 0.725944 \\
\hline & Mar 2006 & 0.339703 & 0.452933 \\
\hline & Apr 2006 & 0.441408 & 0.494285 \\
\hline & Jun 2006 & 0.345064 & 0.728788 \\
\hline & Jul 2006 & 0.380813 & 0.702739 \\
\hline & Aug 2006 & 0.51552 & 0.860817 \\
\hline \multirow[t]{5}{*}{ Mezaira } & Jul 2004 & 0.36782 & 0.536964 \\
\hline & Aug 2004 & 0.38091 & 0.617358 \\
\hline & Sep 2004 & 0.328915 & 0.526263 \\
\hline & Mar 2010 & 0.314758 & 0.453755 \\
\hline & May 2014 & 0.367042 & 0.634481 \\
\hline Sedé Boqer & May 2003 & 0.331628 & 0.454896 \\
\hline Cairo EMA & Apr 2005 & 0.440351 & 0.609703 \\
\hline \multirow[t]{5}{*}{ Saada } & Jul 2004 & 0.348132 & 0.455605 \\
\hline & Aug 2005 & 0.312071 & 0.566701 \\
\hline & May 2006 & 0.327604 & 0.669969 \\
\hline & Aug 2007 & 0.335435 & 0.66549 \\
\hline & Jul 2011 & 0.321371 & 0.599259 \\
\hline \multirow[t]{5}{*}{ Ben Salem } & May 2013 & 0.176807 & 0.776106 \\
\hline & Jun 2013 & 0.155888 & 0.796066 \\
\hline & Sep 2013 & 0.210805 & 0.755659 \\
\hline & May 2014 & 0.193105 & 0.761131 \\
\hline & Jul 2014 & 0.249383 & 0.701042 \\
\hline
\end{tabular}

Over the Solar Village, large dust events were recorded during March-July with peak AOD observed in June 2009 (0.84), May 2009 (0.68), May 2006 (0.67), May 2003 (0.65), May $2011(0,63)$, and March $2012(0.59)$. It is clear that 
Table 6. Seasonal clear events over study locations.

\begin{tabular}{|c|c|c|c|}
\hline & & Clean & \\
\hline \multirow[t]{10}{*}{ Solar Village } & Nov 1999 & 0.149764 & 0.550323 \\
\hline & Jan 2003 & 0.096228 & 0.62666 \\
\hline & Oct 2003 & 0.178413 & 0.733404 \\
\hline & Mar 2004 & 0.191491 & 0.655569 \\
\hline & Oct 2005 & 0.18837 & 0.779462 \\
\hline & Nov 2005 & 0.191312 & 0.86848 \\
\hline & Oct 2006 & 0.180977 & 0.694947 \\
\hline & Dec 2007 & 0.176361 & 0.899631 \\
\hline & Dec 2009 & 0.172281 & 0.825395 \\
\hline & Jan 2010 & 0.124348 & 0.712725 \\
\hline Mezaira & Sep 2013 & 0.281399 & 0.792686 \\
\hline \multirow[t]{8}{*}{ Sedé Boqer } & May 2000 & 0.159897 & 0.605992 \\
\hline & Mar 2006 & 0.184774 & 0.75678 \\
\hline & Jun 2006 & 0.173092 & 0.765389 \\
\hline & Oct 2010 & 0.183684 & 0.67544 \\
\hline & Mar 2013 & 0.182458 & 0.506042 \\
\hline & Apr 2014 & 0.149829 & 0.625146 \\
\hline & May 2014 & 0.162358 & 0.72418 \\
\hline & Jun 2014 & 0.188386 & 0.799814 \\
\hline \multirow[t]{19}{*}{ Tamanrasset } & Oct 2006 & 0.150022 & 0.312346 \\
\hline & Nov 2006 & 0.058332 & 0.711289 \\
\hline & Feb 2007 & 0.07994 & 0.543037 \\
\hline & Mar 2007 & 0.277462 & 0.350458 \\
\hline & Apr 2007 & 0.26391 & 0.250456 \\
\hline & Sep 2007 & 0.256329 & 0.490798 \\
\hline & Oct 2007 & 0.123111 & 0.613251 \\
\hline & Aug 2008 & 0.262444 & 0.5155 \\
\hline & Oct 2008 & 0.259001 & 0.270847 \\
\hline & Nov 2008 & 0.090616 & 0.532111 \\
\hline & Dec 2008 & 0.058681 & 0.712297 \\
\hline & Jan 2009 & 0.061793 & 0.572664 \\
\hline & Dec 2012 & 0.055298 & 0.74645 \\
\hline & Feb 2013 & 0.055164 & 0.714122 \\
\hline & Mar 2013 & 0.110328 & 0.509167 \\
\hline & Jul 2013 & 0.284419 & 0.319017 \\
\hline & Sep 2013 & 0.234119 & 0.209053 \\
\hline & Oct 2013 & 0.073054 & 0.571297 \\
\hline & Nov 2013 & 0.051243 & 0.623209 \\
\hline
\end{tabular}

March is the month with the most frequent dust activity as major dust storms frequently blow during this time of the year. This would also indicate a higher probability of dust transportation within Saudi Arabia and the Arabian Peninsula during March. The major dust event that took place in March 2009 over Saudi Arabia could have contributed to the high AOD observed during this period, with a widespread heavy atmospheric dust load which was reported in Alharbi et al. (2013) and Farahat et al. (2016), who also suggested that the major plume of the March 2009 dust outbreak originated from several dust source areas extending across two regions - the Qasīm region lying some $500 \mathrm{~km}$ northwest of
Riyadh within an active dust source region (Alharbi, 2009) and the Ad Dibdibah and Aș Şummān Plateau region, which is a major source of frequent dust storms in Saudi Arabia. Parts of it are in Iraq, and the south of Kuwait covers the northeastern part of the Ad Dahnā Desert. Alharbi et al. (2013) and Farahat et al. (2016) also reported that this storm was associated with an increase in AOD, wind speed, and a reduction in temperature and visibility, for few days following the storm. Similar AOD pattern was observed over the Bahrain and Mezaira stations with peak AOD observed in March 2012 (0.59) and June 2010 (0.49) over Mezaira and in May 2006 (0.45) over Bahrain. It is important to mention that the Bahrain station did not produce any data after October 2006.

Based on the available data, dust dominates over Cairo during March and April, which is coincident with khamsin storms, in which major dust plumes are transported from the Sahara to eastern Europe. It is clear that most of the year pollution episodes took place over Cairo with peak pollution during November-January with another peak $\left(\alpha_{\text {ext }}\right)$ observed in January 2006 (1.35), November 2005 (1.30), and December 2004 (1.29). This could be attributed to the activity of Egyptian farmers burning rice straw and other agricultural waste during this time of the year. As a result pollution events during these months could be contributing to direct and indirect radiative forcing by anthropogenic aerosols. These results agree with El-Askary et al. (2009) where peaks of biomass burning were found to occur in September (2001 and 2002) and in October (2003 and 2004) over the greater Nile Delta region as observed from the MODIS Terra satellite. El-Askary et al. (2009) also indicated that the long-range pollution observed over Cairo could be attributed to transport from southeast Europe.

Pollution dominates over the Solar Village, Bahrain, and Mezaira sites from October to December with $\alpha_{\text {ext }}$ during October 2012 (1.12), October 2007 (1.06), December 2010 (1.04), and December 2006 (1.02) over the Solar Village; December 2004 (1.29), October 2005 (1.22), December (1.21), and November 2005 over Bahrain; and November 2010 (1.39), January 2010 (1.35), November 2008 (1.25), and January 2014 (1.24) over Mezaira. Pollution over the three sites is in general attributed to a boom in the oil industry accompanied by large infrastructure requirements, the establishment of major cement industry in the area, an unprecedented high economic growth rate, low energy costs subsidized by the government, and a population increase. These all contribute to Saudi Arabia, Bahrain, and UAE environmental pollution (Farahat, 2016). Winter pollution dominates from October to December due to a reduction in dust blowing events over these months, which is an indicator of less pollution transport during that period. Clean scenarios are observed over the Solar Village, Bahrain, and Mezaira mostly during the summer season; this is probably due to less traffic pollution as schools are off and many locals travel to cooler places to escape high summer temperatures in this 

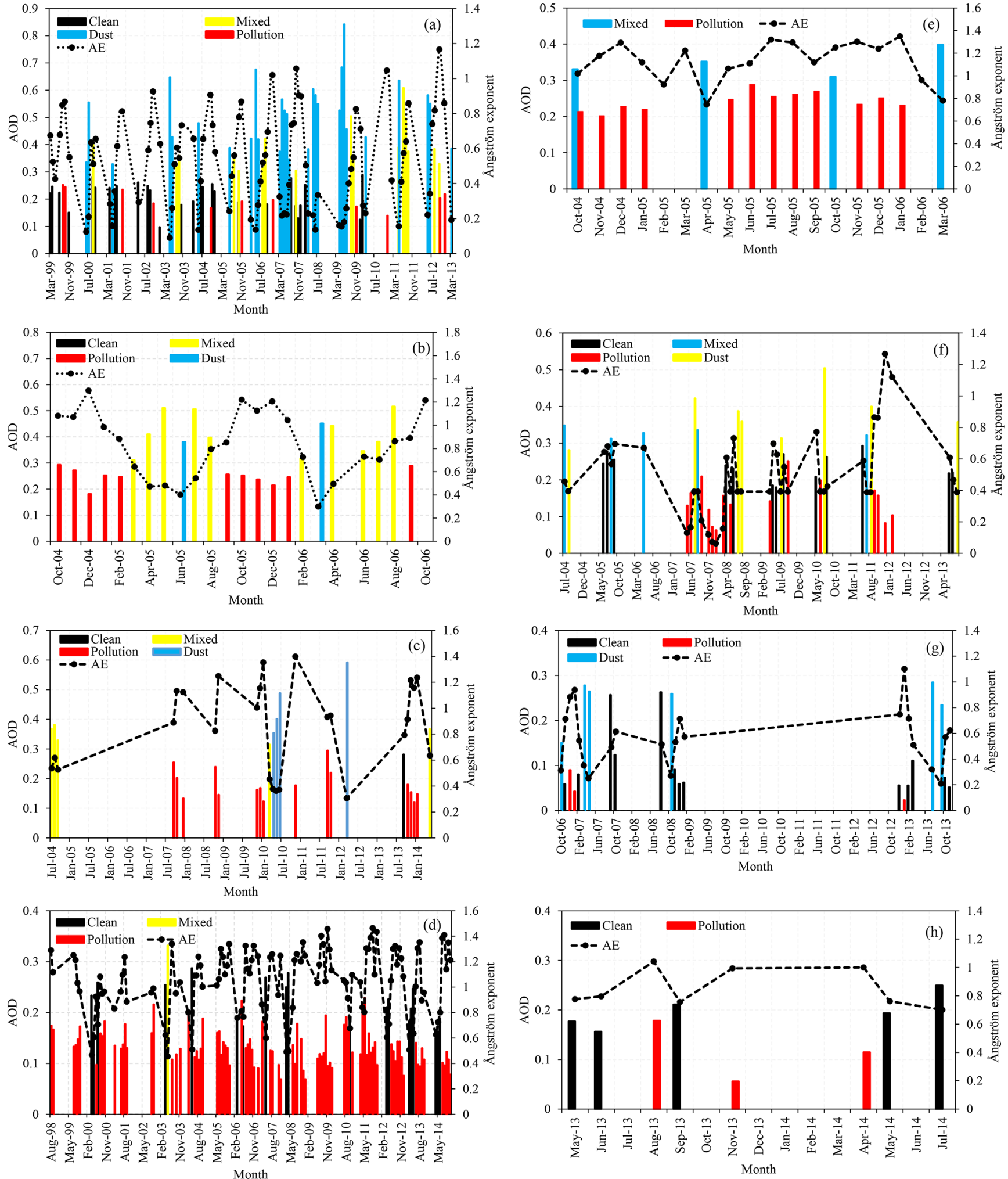

Figure 4. Measurements and occurrence for different aerosol particle categories and their corresponding absorption Ångström exponents (monthly average) over (a) Solar Village; (b) Bahrain; (c) Mezaira; (d) Sedé Boqer; (e) Cairo; (f) Saada; (g) Tamanrasset; (h) Ben Salem. 

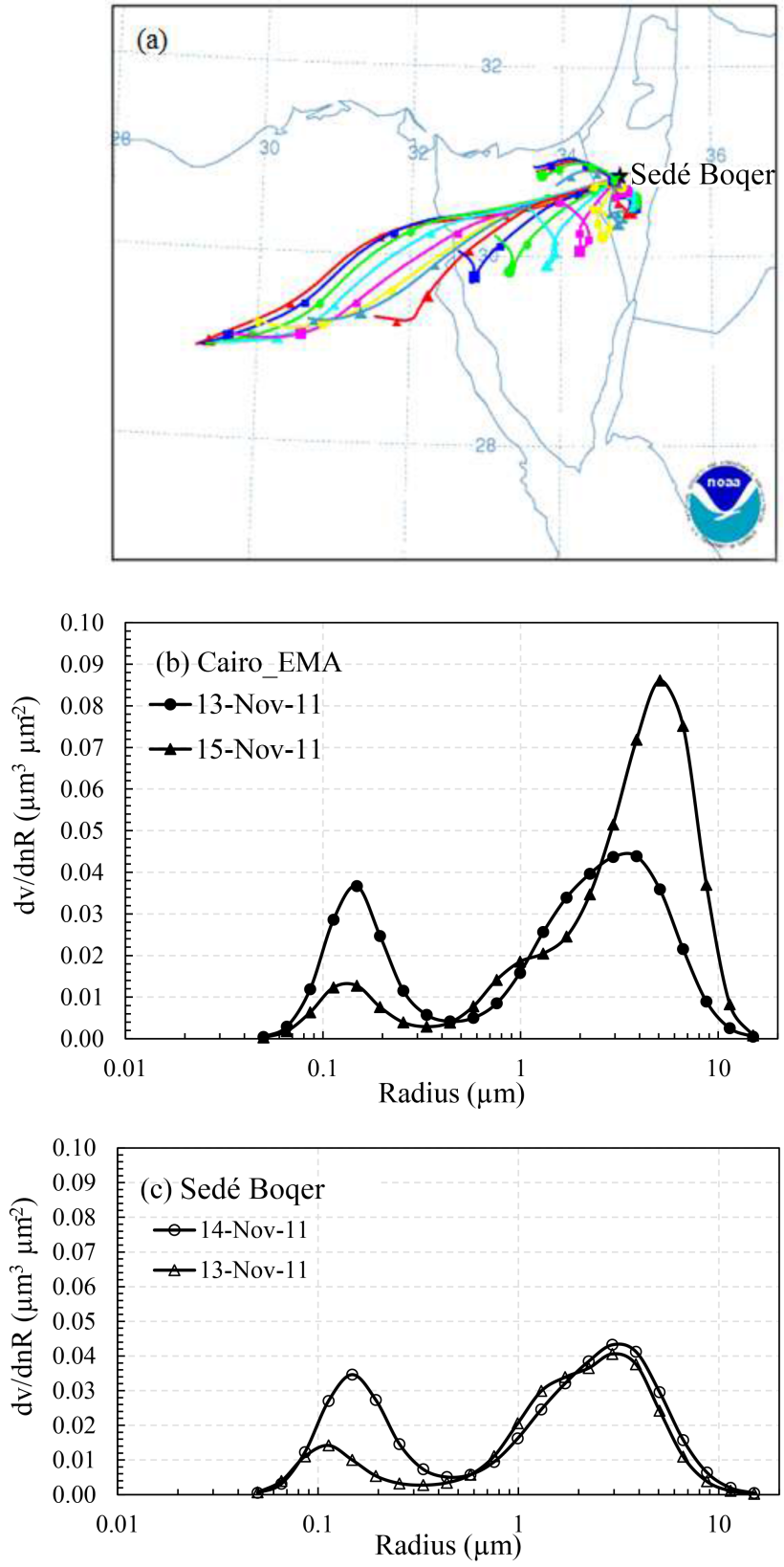

Figure 5. (a) HYSPLIT backward trajectory on 14 November 2011 at Sedé Boqer site showing aerosol possible transport from Cairo site; (b) volume size distribution at Sedé Boqer site during 13 and 14 November 2011; (c) volume size distribution at Cairo_EMA site during 13 and 15 November 2011.

area. However, clean weather is also observed during other months based on weather conditions and aerosol transport.

Compared to the Solar Village, Bahrain, and Mezaira sites, lower AOD values are recorded at the Tamanrasset and Saada sites during the dust season, but higher pollution is observed during November-February with $\alpha_{\text {ext }}$ January 2013 (1.10) over Tamanrasset; December 2007 (1.45), January
2008 (1.45), and December 2011 (1.26) over Saada; and August 2013 (1.04) over Ben Salem. Microparticle transport plays a major factor in changing aerosol types at different AERONET sites. In this article, we try to shed light on a possible aerosol transport between two AERONET sites, namely Cairo and Sedé Boqer. The two sites are chosen based on their geographic locations to demonstrate aerosol transport from North Africa to the Middle East. Aerosols volume size distribution on 13 November 2011 over the Cairo site and on 14 November 2011 over the Sedé Boqer site ( $24 \mathrm{~h}$ later) clearly shows aerosol transport between the two sites (Fig. 5). The Hybrid Single Particle Lagrangian Integrated Trajectory (HYSPLIT) back trajectory model confirms the possible aerosol transport from Cairo to Sedé Boqer. Gridded meteorological data, at regular time intervals, are used in the calculation of air mass trajectories. For the back-trajectories, data are obtained from existing archives. A complete description of input data, methodology, equations involved, and sources of error for the calculation of the air mass trajectory is presented by Draxler and Hess (1997). Figure 5a shows the air mass back trajectory at Sedé Boqer during the black cloud local pollution episode over the Delta Region at different vertical elevations to highlight the vertical extent of local transportation (Aboel Fetouh et al., 2013; Prasad et al., 2010). El-Askary and Kafatos (2008) found that an inversion layer contributes to the trapping of aerosols and pollutants, resulting in an increase of their concentration and, hence, creating a permanent haze that can develop into a health hazard. Figure $5 \mathrm{~b}$ and $\mathrm{c}$ show the SSA characteristics over both locations, implying the transport from Cairo location to Sedé Boqer. SSA values at the finer radius size were high on the 13th over Cairo and low over Sedé Boqer; then SSA values increased on the 14th over Sedé Boqer while showing a drop on the 15th over Cairo. This behavior suggests aerosol transport from Cairo to Sedé Boqer during the period under investigation. The preliminary results here demonstrate a possible aerosol transport between different sites; however, a complete spatial and temporal analysis is needed to understand the effect of this transport on aerosol types.

\section{Conclusions}

A combination of ground-based aerosol-related parameters was used in this analysis to study different sources of aerosol loadings over eight different cities in North Africa and the Gulf region. Our analysis involved a study of the AOD and SSA, as well as other derived parameters and trajectory models. Natural vs. anthropogenic aerosols are well distinguished using our derived Ångström exponent. We also identified possible mixed and clean atmospheric conditions using the calculated $\alpha 675 / 440$ values. It is clear that dust episodes dominate the spring season, as reflected by the high values of AOD associated with sharp drops in the Ångström exponent. Back trajectory analysis shows agreement with these findings, thereby confirming that the Sahara is the major source 
of such aerosols during the spring season. Furthermore, the sharp peaks in the Ångström exponent at the Cairo station suggests a possible long-range transport of pollutants from Europe during the summer season as previously discussed by El-Askary et al. (2009). Local pollution is most prominent during the fall and winter seasons, as confirmed by the data presented in the tables and associated figures. In summary, it is clear that the region under investigation is exposed to the impacts of aerosols from various sources throughout the year. This is becoming a serious health hazard because of the persistence of high pollution throughout the year or for prolonged time periods.

\section{Data availability}

All data used in this study are publicly available at the Aerosol Robotic Network (AERONET, 2016) homepage: http://aeronet.gsfc.nasa.gov/.

Acknowledgements. The authors would like to acknowledge the support provided by the Deanship of Scientific Research (DSR) at the King Fahd University of Petroleum and Minerals (KFUPM) for funding this work through project no. IN121064. The authors would like to also extend their thanks and appreciation to the principle investigators and their staff for establishing and maintaining the different AERONET sites (http://aeronet.gsfc.nasa.gov/) used in this investigation.

The topical editor, M. Salzmann, thanks three anonymous referees for help in evaluating this paper.

\section{References}

Abdi Vishkaee, F., Flamant, C., Cuesta, J., Oolman, L., Flamant, P., and Khalesifard, H.: Dust transport over Iraq and northwest Iran associated with winter shamal: a case study, J. Geophys. Res., 117, D03201, doi:10.1029/2011JD016339, 2012

Aboel Fetouh, Y., El-Askary, H., El Raey, M., Allali, M., Sprigg, W. A., and Kafatos, M.: Annual Patterns of Atmospheric Pollutions and Episodes over Cairo Egypt. Advances in Meteorology, 2013, 984853, doi:10.1155/2013/984853, 2013.

AERONET: Aerosol Characteristics, available at: http://aeronet. gsfc.nasa.gov/, last access: 15 November 2016.

Agarwal, A., El-Askary, H., El-Ghazawi, T., Kafatos, M., and Le-Moigne, J.: Efficient PCA Fusion Techniques for MISR Multi-angle Observations with Applications to Monitoring Dust Storms. IEEE Geosci. Remote S., 4, 678-682, doi:10.1109/LGRS.2007.904467, 2007.

Alharbi, B., Maghrabi, A., and Tapper N.: The March 2009 Dust Event in Saudi Arabia: Precursor and Supportive Environment, B. Am. Meteorol. Soc., 94, 515-528, 2013.

Alados-Arboledas, L., Lyamani, H., and Olmo, F. J.: Aerosol size properties at Armilla, Granada (Spain), Q. J. Roy. Meteor. Soc., 129, 1395-1413, 2003.

Alharbi, B. H.: Airborne dust in Saudi Arabia: Source areas, entrainment, simulation and composition. Ph.D. dissertation,
Monash University, 313 pp., and Moied, K., 2005: Riyadh air quality report (1999-2004), King Abdulaziz City for Science and Technology 279-25-ER, 116 pp., 2009.

Ångström, A.: The parameters of atmospheric turbidity, Tellus A, 16, 64-75, 1964.

Basart, S., Pérez, C., Cuevas, E., Baldasano, J. M., and Gobbi, G. P.: Aerosol characterization in Northern Africa, Northeastern Atlantic, Mediterranean Basin and Middle East from direct-sun AERONET observations, Atmos. Chem. Phys., 9, 8265-8282, doi:10.5194/acp-9-8265-2009, 2009.

Chin, M., Ginoux, P., Kinne, S., Torres, O., Holben, B., Duncan, B., Martin, R., Logan, J., Higurashi, A., and Nakajima, T.: Tropospheric aerosol optical thickness from the GOCART model and comparisons with satellite and Sun photometer measurements, J. Atmos. Sci., 59, 461-483, 2002.

Derimian, Y., Karnieli, A., Kaufman, Y. J., Andreae, M. O., Andreae, T. W., Dubovik, O., Maenhaut, W., Koren, I., and Holben, B. N.: Dust and pollution aerosols over the Negev desert, Israel: Properties, transport, and radiative effect, J. Geophys. Res., 111, D05205, doi:10.1029/2005JD006549, 2006.

Draxler, R. R. and Hess, G. D.: Description of the HYSPLIT_4 modeling system, NOAA, Technical Memorandum ERL ARL224, 24 pp., 1997.

Dubovik, O. and King, M. D.: A flexible inversion algorithm for retrieval of aerosol optical properties from Sun and sky radiance measurements, J. Geophys. Res., 105, 20673-20696, 2000.

Dubovik, O., Holben, B., Eck, T., Smirnov, A., Kaufman, Y., King, M., Tanre, D., and Slutsker, I.: Variability of absorption and optical properties of key aerosol types observed in worldwide locations, J. Atmos. Sci., 59, 590-608, 2002.

Eck, T., Holben, B., Reid, J., Dubovik, O., Smirnov, A., O’Neill, N., Slutsker, I., and Kinne, S.: Wavelength dependence of the optical depth of biomass burning, urban, and desert dust aerosols, J. Geophys. Res., 104, 31333-31349, 1999.

Eck, T., Holben, B., Reid, J., O’Neill, N., Schafer, J., Dubovik, O., Smirnov, A., Yamasoe, M., and Artaxo, P.: High aerosol optical depth biomass burning events: A comparison of optical properties for different source regions, Geophys. Res. Lett., 30, 2035, doi:10.1029/2003GL017861, 2003.

Eck, T. F., Holben, B. N., Sinyuk, A., Pinker, R. T., Goloub, P.,Chen, H., Chatenet, B., Li, Z., Singh, R. P., Tripathi, S. N., Reid, J. S., Giles, D. M., Dubovik, O., O’Neill, N. T., Smirnov, A., Wang, P., and Xia X.: Climatological aspects of the optical prop-erties of fine/coarse mode aerosol mixtures, J. Geophys. Res., 115, D19205, doi:10.1029/2010JD014002, 2010

El-Askary, H.: Air pollution Impact on Aerosol Variability over mega cities using Remote Sensing Technology: Case study, Cairo, The Egyptian Journal of Remote Sensing and Space Sciences, 9, 31-40, 2006.

El-Askary, H. and Kafatos, M.: Dust Storm and Black Cloud Influence on Aerosol Optical Properties over Cairo and the Greater Delta Region, Egypt, Int. J. Remote Sens., 29, 7199-7211, 2008.

El-Askary, H., Farouk, R., Ichoku, C., and Kafatos, M.: Transport of dust and anthropogenic aerosols across Alexandria, Egypt, Ann. Geophys., 27, 2869-2879, doi:10.5194/angeo-27-28692009, 2009.

El-Askary, H., Park, S. K., Ahn, M. H., Prasad, A., and Kafatos, M.: On the detection and monitoring of the transport of an Asian 
dust storm approaching the Korean Peninsula, J. Environ. Inf. 25, 99-116, 2015.

El-Metwally, M., Alfaro, S. C., AbdelWahab, M., and Chatenet, B.: Aerosol characteristics over urban Cairo: Seasonal variations as retrieved from Sun photometer measurements, J. Geophys. Res., 113, D14219, doi:10.1029/2008JD009834, 2008.

Farahat, A.: Air Pollution in Arabian Peninsula (Saudi Arabia, United Arab Emirates, Kuwait, Qatar, Bahrain, and Oman): Causes, Effects and Aerosol Categorization, Arab J. Geosci., 9, 196, doi:10.1007/s12517-015-2203-y, 2016.

Farahat, A., El-Askary, H., and Al-Shaibani, A.: Study of Aerosols' Characteristics and Dynamics over the Kingdom of Saudi Arabia using a Multi Sensor Approach Combined with Ground Observations, Advances in Meteorology, 2015, 247531, doi:10.1155/2015/247531, 2015.

Farahat, A., El-Askary, H., and Dogan, U.: Aerosols size distribution characteristics and role of precipitation during dust storm formation over Saudi Arabia, Aerosol Air Qual. Res., in press, 2016

Gathman, S. G.: Optical properties of the marine aerosol as predicted by the Navy aerosol model, Opt. Eng., 22, 57-62, 1983.

Gerasopoulos, E., Amiridis, V., Kazadzis, S., Kokkalis, P., Eleftheratos, K., Andreae, M. O., Andreae, T. W., El-Askary, H., and Zerefos, C. S.: Three-year ground based measurements of aerosol optical depth over the Eastern Mediterranean: the urban environment of Athens, Atmos. Chem. Phys., 11, 2145-2159, doi:10.5194/acp-11-2145-2011, 2011.

Gerasopoulos, E., Andreae, M. O., Zerefos, C. S., Andreae, T. W., Balis, D., Formenti, P., Merlet, P., Amiridis, V., and Papastefanou, C.: Climatological aspects of aerosol optical properties in Northern Greece, Atmos. Chem. Phys., 3, 2025-2041, doi:10.5194/acp-3-2025-2003, 2003.

Giles, D. M., Holben, B. N., Eck, T. F., Sinyuk, A., Smirnov, A., Slutsker, I., Dickerson, R. R., Thompson, A. M., and Schafer, J. S.: An analysis of AERONET aerosol absorption properties and classifications representative of aerosol source regions, J. Geophys. Res., 117, D17203, doi:10.1029/2012JD018127, 2012.

Gobbi, G. P., Kaufman, Y. J., Koren, I., and Eck, T. F.: Classification of aerosol properties derived from AERONET direct sun data, Atmos. Chem. Phys., 7, 453-458, doi:10.5194/acp-7-453-2007, 2007.

Goudie, A. S. and Middleton, N. J.: Saharan dust storms: nature and consequences, Earth-Sci. Rev., 56, 179-204, 2011.

Gras, J. L.: CN, CNN and particle size in Southern Ocean air at Cape Grim, Atmos. Res., 35, 233-251, 1995.

Holben, B. N., Eck, T. F., Slutsker, I., Tanré, D., Buis, J. P., Setzer, A., Vermote, E., Reagan, J. A., Kaufman, Y. J., Nakajima, T., Lavenu, F., Jankowiak, I., and Smirnov, A.: AERONET: A federated instrument network and data archive for aerosol characterization, Remote Sens. Environ., 66, 1-16, 1998.

Holben, B., Tanré, D., Smirnov, A., Eck, T., Slutsker,I., Abuhassan, N., Newcomb, W., Schafer, J., Chatenet, B., Lavenu, F., Kaufman, Y., Vande Castle, J., Setzer, A., Markham, B., Clark, D., Frouin, R., Halthore, R., Karneli, A., O’Neill, N., Pietras, C., Pinker, R., Voss, K, and Zibordi, G.: An emerging ground-based aerosol climatology: Aerosol optical depth from AERONET, J. Geophys. Res., 106, 12067-12097, doi:10.1029/2001JD900014, 2001.
Kalapureddy, M. C. R. and Devara, P. C. S.: Characterization of aerosols over oceanic regions around India during pre-monsoon 2006, Atmos. Environ., 42, 6816-6827, 2008.

Kaskaoutis, D. G. and Kambezidis, H. D.: Investigation on the wavelength dependence of the aerosol optical depth in the Athens area, Q. J. Roy. Meteor. Soc., 132, 2217-2234, 2006.

Kaskaoutis, D. G., Prasad, A. K., Kosmopoulos, P. G., Sinha, P. R., Kharol, S. K., Gupta, P., El-Askary, H. M., and Kafatos, M.: Synergistic use of remote sensing and modeling for tracing dust storms in the Mediterranean, Advances in Meteorology, 2012, 861026, doi:10.1155/2012/861026, 2012.

Kaufman, Y. J., Gitelson, A., Karnieli, A., Ganor, E., Fraser, R. S., Nakajima, T., Mattoo, S., and Holben, B. N.: Size distribution and scattering phase function of aerosol particles retrieved from sky brightness measurements, J. Geophys. Res., 99, 1034110356, 1994

Kim, D., Chin, M., Yu, H., Eck, T. F., Sinyuk, A., Smirnov, A., and Holben, B. N.: Dust optical properties over North Africa and Arabian Peninsula derived from the AERONET dataset, Atmos. Chem. Phys., 11, 10733-10741, doi:10.5194/acp-1110733-2011, 2011.

Kondo, Y., Sahu, L., Kuwata, M., Miyazaki, Y., Takegawa, N., Moteki, N., Imaru, J., Han, N. S., Nakayama, T., Kim-Oanh, N. T., Hu, M., Kim, Y. J., and Kita, K.: Stabilization of the Mass Absorption Cross Section of Black Carbon for Filter-Based Absorption Photometry by the Use of a Heated Inlet, Aerosol. Sci. Tech., 43, 741-756, 2009.

Marey, H. S., Gille, J. C., El-Askary, H. M., Shalaby, E. A., and ElRaey, M. E.: Study of the formation of the "black cloud" and its dynamics over Cairo, Egypt, using MODIS and MISR sensors, J. Geophys. Res., 115, D21206, doi:10.1029/2010JD014384, 2010.

Marey, H. S., Gille, J. C., El-Askary, H. M., Shalaby, E. A., and El-Raey, M. E.: Aerosol climatology over Nile Delta based on MODIS, MISR and OMI satellite data, Atmos. Chem. Phys., 11, 10637-10648, doi:10.5194/acp-11-10637-2011, 2011.

Nakajima, T., Tanaka, M., Yamano, M., Shiobara, M., Arao, K., and Nakanishi Y.: Aerosol optical characteristics in the yellow sand events observed in May, 1982 in Nagasaki, J. Meteorol. Soc. Jpn., 67, 279-291, 1989.

Omar, A. H., Won, J., Winker, D., Yoon, S., Dubovik, O., and McCormick, P.: Development of global aerosol models using cluster analysis of Aerosol Robotic Network (AERONET) measurements, J. Geophys. Res., 110, D10S14, doi:10.1029/2004JD004874, 2005.

Park, S., El-Askary, H., Sabbah, I., Kwak, H., Prasad, A., Lee, W. and Kafatos, M.: Studying air pollutants origin and associated meteorological parameters over Seoul from 2000 to 2009, Advances in Meteorology, 2015, 704178, doi:10.1155/2015/704178, 2015.

Petzold, A., Kopp, C., and Niessner, R.: The dependence of the specific attenuation cross-section on black carbon mass fraction and particle size, Atmos. Environ., 31, 661-672, 1997.

Prasad A. K., El-Askary, H. M., and Kafatos, M.: Implications of high altitude desert dust transport from Western Sahara to Nile Delta during biomass burning season, Environ. Pollut., 158, 3385-3391, 2010.

Qin, Y. and Mitchell, R. M.: Characterisation of episodic aerosol types over the Australian continent, Atmos. Chem. Phys., 9, 1943-1956, doi:10.5194/acp-9-1943-2009, 2009. 
Ramanathan, V., Cess, R. D., Harrison, E. F., Minnis, P., Barkstrom, B. R., Ahmed, E., and Hartmann, D.: Cloud-radiative forcing and climate: Results from the earth radiation budget experiment, Science, 243, 57-63, 1989.

Reid, J. S., Eck, T. F., Christopher, S. A., Hobbs, P. V., and Holben, B.: Use of the Angstrom exponent to estimate the variability of optical and physical properties of aging smoke particles in Brazil, J. Geophys. Res., 104, 27473-27489, 1999.

Russell, P. B., Bergstrom, R. W., Shinozuka, Y., Clarke, A. D., DeCarlo, P. F., Jimenez, J. L., Livingston, J. M., Redemann, J., Dubovik, O., and Strawa, A.: Absorption Ångstrom Exponent in AERONET and related data as an indicator of aerosol composition, Atmos. Chem. Phys., 10, 1155-1169, doi:10.5194/acp-101155-2010, 2010.

Said, S. and Kadry, H.: Generation of representative weather - Year data for Saudi Arabia, Appl. Energ., 48, 131-136, 1994.

Satheesh, S. K. and Moorthy, K. K.: Radiative effects of natural aerosols: A review, Atmos. Environ., 39, 2089-2110, 2005.

Sokolik, I. N. and Toon, O. B.: Incorporation of mineralogical composition into models of the radiative properties of mineral aerosol from UV to IR wavelengths, J. Geophys. Res., 104, 9423-9444, 1999.

Smirnov, A., Holben, B. N., Eck, T. F., Dubovik, O., and Slutsker: Cloud-screening and quality control algorithms for the AERONET database, Remote Sens. Environ., 73, 337-349, 2000 .
Smirnov, A., Holben, B. N., Dubovik, O., O’Neill, N. T., Eck, T. F., Westphal, D. L., Goroch, A. K., Pietras, C., and Slutsker, I.: Atmospheric aerosol optical properties in the Persian gulf, J. Atmos. Sci., 59, 620-634, 2002.

Sprigg, W., Nickovic, S., Galgiani, J. N., Pejanovic, G., Petkovic, S., Vujadinovic, M., Vukovic, A., Dacic, M., DiBiase, S., Prasad, A., and El-Askary, H.: Regional dust storm modelling for health services: the case of valley fever, J. of Aeol. Res., 14, 53-73, ISSN 1875-9637, 2014.

Takemura, T., Okamoto, H., Maruyama, Y., Numaguti, A., Higurashi, A., and Nakajima, T.: Global three-dimensional simulation of aerosol optical thickness distribution of various origins, J. Geophys. Res., 105, 17853-17873, 2000.

Taylor, M., Kazadzis, S., Tsekeri, A., Gkikas, A., and Amiridis, V.: Satellite retrieval of aerosol microphysical and optical parameters using neural networks: a new methodology applied to the Sahara desert dust peak, Atmos. Meas. Tech., 7, 3151-3175, doi:10.5194/amt-7-3151-2014, 2014.

Vukovic, A., Vujadinovic, M., Pejanovic, G., Andric, J., Kumjian, M. R., Djurdjevic, V., Dacic, M., Prasad, A. K., El-Askary, H. M., Paris, B. C., Petkovic, S., Nickovic, S., and Sprigg, W. A.: Numerical simulation of "an American haboob", Atmos. Chem. Phys., 14, 3211-3230, doi:10.5194/acp-14-3211-2014, 2014. 